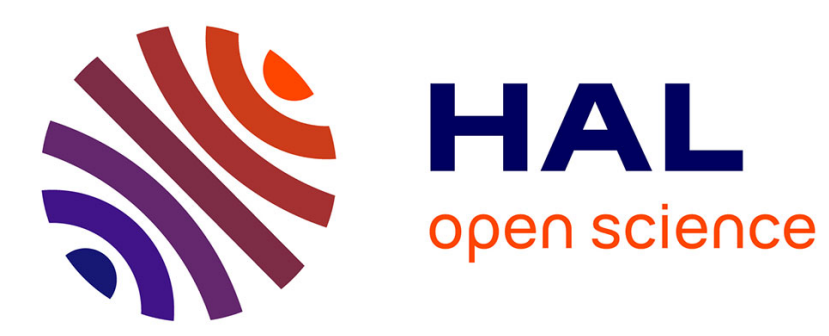

\title{
Reconstituting the Public-Private Divide under Global Conditions
}

\author{
Willemijn Dicke, Martin Albrow
}

\section{To cite this version:}

Willemijn Dicke, Martin Albrow. Reconstituting the Public-Private Divide under Global Conditions. Global Social Policy, 2005, 5 (2), pp.227-248. 10.1177/1468018105053680 . hal-00571781

\section{HAL Id: hal-00571781 \\ https://hal.science/hal-00571781}

Submitted on 1 Mar 2011

HAL is a multi-disciplinary open access archive for the deposit and dissemination of scientific research documents, whether they are published or not. The documents may come from teaching and research institutions in France or abroad, or from public or private research centers.
L'archive ouverte pluridisciplinaire HAL, est destinée au dépôt et à la diffusion de documents scientifiques de niveau recherche, publiés ou non, émanant des établissements d'enseignement et de recherche français ou étrangers, des laboratoires publics ou privés. 


\title{
Reconstituting the Public- Private Divide under Global Conditions
}

\author{
The Case of Dutch and British Water Management
}

\author{
WILLEMIJN DICKE \\ Delft University of Technology, The Netherlands \\ MARTIN ALBROW \\ Independent Scholar, London
}

A в STRACT How is the line to be drawn in the public-private divide when those who would bridge it also assert that globalization restricts the state's ability to deliver public policy objectives? Critics of modernity have seen the distinction between two public-private discourses, state and market, the open and the hidden, as a modern flawed version of classic notions of the democratic citizen community. The projection of the divide on to a global stage appears to take us even further from that ideal. We report the results of a narrative analysis of the way practitioners in the Netherlands and England and Wales now deliver global public goods in the management of water as compared with their predecessors delivering public health and progress in the 19th century. In their adherence to the water systems concept we find them actively supporting a transparent public sphere beyond the state where multiple forms of agency assert global responsibilities.

KEYWORDS globalization, narrative analysis, public-private divide, transparency, water management 


\section{Introduction}

Public policy debates have an inbuilt tendency to revert to the fraught question of the public-private divide: How is the line to be drawn between them? But there is not just one divide, there are many, including two main ones: first, that the state is responsible for the public good while private interests rule the market; and, second, that public life is open, visible and impersonal, quite distinct from the intimacy of private life.

Critics of modernity have seen the separation of the two divides as a modern distortion of the notion of the democratic citizen community. But pragmatic compromises between state and market have done little to renew that classic concept, especially when their advocates declare that globalization restricts the modern state's capacity to deliver public welfare.

The state appears even more enfeebled when the public-private divide is projected on to a global stage. The now common references to global public goods beg the question of which agencies can deliver them if nation states have lost the control they had even on national welfare. And the global citizen community as a renewal of democracy appears even more utopian.

Under global conditions the theoretical critique of the modern public-private divide clearly requires re-examination. But our main intention is to ground that with an empirical case study of the way national agencies handle the global public-private divide. While these issues demand answers in principle, they are resolved for practical purposes in the ongoing work of policy makers.

The public-private divide has its roots in the early history of the West. Its reach is now global. To achieve the necessary historical and comparative scope that theory requires, and simultaneously to provide substantive depth, we have chosen as a case study the management of water, a universal problem of the human condition, ancient, modern or global.

\section{Modernity's Public-Private Divides}

Pragmatic compromises between the public and private might be easier if the divide were clear-cut in the first place. There is, however, not just one publicprivate divide, but many, that range across our lives, cross-cutting each other in a confusion of ways. Everyday language in Britain reflects this confusion. 'Public schools' are charities that charge fees; shareholders own 'public corporations'; the state guards the public interest with 'official secrets'; surveys glean 'public opinion' from private and confidential interviews. 'Public policy' in Britain seems to suggest an impending state takeover of welfare concerns. On the other hand, in the USA long-standing promotion of the idea of the 'public interest' and more recently 'public philosophy' implies spheres of politics and letters beyond and even critical of the state. Political context and 
national culture then clearly set parameters for drawing the divide and one of our purposes in this article is to advance understanding of the divide in contemporary policy debates through researching context and culture.

Previous work on the language of the public-private divide provides us with an initial orientation. Weintraub's (1997: 36) wide-ranging historical discussion of clusters of meanings and connotations identifies fields of discourse made up of broad 'families of oppositions'. Drawing on him we will distinguish three divides.

\section{STATE ADMINISTRATION VERSUS THE MARKET ECONOMY}

Neoliberals and socialists provide accounts of the public-private divide in terms of the opposition of state and market that draw their inspiration from the English speaking individualism of Locke, Hobbes, Smith and Bentham. Although opinions differ on the degree to which individuals and organizations are able to harmonize self-interests, or the degree to which coercion is needed, there is general agreement that the distinction between the private sector consisting of individuals and organizations, freely pursuing their selfinterest, and the state exercising coercion for collective ends should be drawn as clearly and sharply as possible.

Long couched in terms of the 'problem of bureaucracy', this family of oppositions includes cumbersome versus lean, inefficient versus efficient, hidebound versus innovative, lifelong career versus flexible employment, citizen versus customer. In this discourse organizations that pursue their own goals are deemed to be 'private'; owned by the state they become public, and hence inefficient or socially responsible depending on political outlook.

\section{IN THE OPEN VERSUS HIDDEN}

Here the public sphere houses innumerable visible encounters between a multiplicity of individuals, a complex framework of institutions that facilitates relations at a distance and a diffused set of ideas transmitted through the mass media. What happens in this sphere, 'in public', contrasts with domestic life, with the inner thoughts of the individual, with the concealed nature of intimate personal relations. The tradition of thought that underpins this publicprivate field of discourse is more recent and contained in accounts of the distinctiveness of modern life. In Norbert Elias's (1939/1978/1982) seminal account the increasing split between public life and the intimate sphere is definitive of advances in civilization itself. But significantly he links the emergence of this intimate sphere precisely to an increase in state control, in particular to its monopolization of the means of violence, in the modern period. In other words his theory offers an account of the conjoint emergence of both the first and this second public-private divide, and attributes their separation to modernity. 
THE COMMUNITY OF CITIZENS VERSUS PERSONAL INTERESTS

The ambiguity and confusion arising from the existence of the two fields of public-private discourse (for instance the market is private in the first version and public in the second) has made their separation a prime target for critics of modernity. Shorn of visibility state control makes secrecy a virtue, deprived of political responsibility public opinion becomes the prejudices of mass man. Hannah Arendt (1958) proposed that it was modern mass society that distorted the original classic divide. The critics of modernity discover its defects against a template of a democratic community with roots in the ancient European world. The most influential, Jürgen Habermas (1962/ 1989), advances a largely counterfactual vision of a single coherent public sphere coalescing through the open communication of private interests and values in democratic institutions. The image of the gathering of citizens in the public forum resolving matters of common concern, has been conveyed through two millennia via the Latin root 'public-', connoting, from the earliest time, both 'in public' and 'of the people'. Thus the small scale of the self-governing city community has remained an abiding standard for democratic thought through the modern period until today. This unification of the two fields of discourse constitutes the third field of discourse for the public-private divide in our time. The open issue is whether any of the three can provide adequate accounts for the policy problems of a globalized world.

\section{The Challenge of Globality}

As a counterfactual vision of the public democratic sphere, Habermas' account is itself open to the self-criticism he enshrines at its centre. The most telling objections arise out of contemporary multiculturalist thinking. Craig Calhoun argues for the central importance of 'public' 'both as the crucial subject of democracy - the people organized as a discursive, decision-making public - and as object - the public good' (Calhoun, 1997: 81). But he denies the possibility of creating a single public discourse without effectively privileging one group over others. We have to acknowledge, he argues, a multiplicity of publics, and these publics are not (and never truly were, in spite of the ambitions of the modern nation state) contained within a single state. In alluding to a sphere of publics crossing state boundaries, Calhoun's account is consistent with contemporary conditions of transnational flows of people and goods and the rise of global issues of concern beyond boundaries. He thus brings into the open an underlying problem that none of the three fields of discourse address directly, namely, who the people are that are divided along the public-private line, however drawn. Do, and if so how do, these people as individuals or associations constitute or act as a collectivity, a public? The first two fields of discourse avoid the issue by disaggregating the collective, the third reassembles it, but assumes that citizenship is unproblematical. 
This issue becomes acute when we consider public goods in a global frame. It is at the core of the emerging theories on global public goods and international regimes. Global goods are defined as goods 'whose benefits cut across several countries and generations, present and future' (Kaul et al., 1999: 11) or as 'commodities, resources services and also systems of rules or policy regimes with substantial cross-border externalities ...' (World Bank, 1993). Some argue for the need for regulatory institutions with a global reach (Biermann and Dingwerth, 2004; Braithwaite and Drahos, 2000; Reinicke and Deng, 2000), others seek resort to new regimes (Deacon, 2003; Krasner, 1982). These are theoretical attempts to catch up with practices that run ahead of older modern public-private discourses. Practical examples are the Global Reporting Initiative (Christen, 2003), which aspires to become the leading standardized system for voluntary reporting of sustainability performance by companies worldwide or the Global Environment Facility (GEF), established in 1991 to help developing countries fund projects and programmes that protect the global environment (GEF, 2004).

In brief, under global conditions we have a multiplicity of agencies securing putative 'global public goods' when even countries can effectively become 'private' interests relative to some undefined wider 'public'. The pervasive and persistent retention of the public-private divide in circumstances not envisaged in the three older discourses suggests that we are experiencing its reconstitution to match the new conditions. For this reason we believe that we need more than the kind of conceptual analysis we have cited and that has hitherto dominated the discussion of the divide. If context and conditions set the parameters for those older discourses, then we need also to advance understanding by empirical research on the context of the new discourse.

\section{Water as a Case of the Public-Private Divide}

We chose to take water as a test case for our research on the new public-private discourse for a number of reasons. No individual or country can, or ever could do without it, nor ignore the need to secure a predictable supply for a vast set of purposes, from drinking, to irrigation, to transport, and to protect also from the ravages that water in excess can bring. Water is a universal necessity for human life and an ever-present threat. Its universality makes it ideal both for historical and comparative research. For Karl Wittfogel (1957) its management was the defining issue for pre-industrial empires. We can track the story of human technical advance through water, equally no country or individual is outside a comparison of relative use of and value placed on water. And of greatest importance for our purposes, water use and management always raises issues of the relative involvement of and benefits accruing to individuals and collectivities.

Water has therefore long been a prime theme when debating refinements 
of the public-private divide. Water management has been defined as comprising the prevention of water nuisance, protection against depletion, safeguarding water quality and the supply of water to its users (Nationale Raad voor Landbouwkundig Onderzoek [NLRO], 2000: 12). Considering public and private goods from this standpoint, we may distinguish cases varying from pure public goods (e.g. flood defence), pure private goods (e.g. purification of water within a factory), club goods, merit goods (e.g. drinking water). Water management comprises also common pool resource aspects (Gardner et al., 1990), for example for the extraction of ground water. Furthermore, water management is a classical example for externalities, both negative (e.g. a firm releases pollution into the nearby river) and positive (water is purified and everybody downstream can enjoy this benefit) (e.g. I. Kaul et al., 1999: 509). Finally, one can distinguish public-private goods on the one hand from services on the other, and in all these cases the question of public or private provision remains. As explained above, we do not believe that the distinction between public and private is pre-given. Instead, it is constructed. A public policy decision may designate goods that are consumed privately as being so important to the fate of the collectivity that it provides for their supply. This multiplicity of public and private aspects of water management means the divide is open to widely different constructions depending on the politics and culture of the people concerned. Indeed it often becomes a litmus test for national differences.

Water may be universal but it is not managed in a universal way, as the two histories of water management in the UK and the Netherlands will illustrate. Each country has its own tradition in conducting water management and drawing the public-private divide. We chose these two countries for our research because of our comparative advantage in access to them, but also because their closeness in so many respects, geographically and historically, both maritime and former colonial countries. We are using them therefore as a test for the influence of cultural difference but also for detecting the influence of cross-border global conditions. Single country research could not deliver these results.

The need to achieve historical depth and cultural range has also dictated our choice of research method. The literature locates the public-private divide firmly in the development of modernity from even older roots. It emphasizes too the exposure of the divide always to prevailing political conditions. As these change so does the divide and its story is located by its interpreters firmly in the history of the modern age.

We shall explore the divide in depth as represented in stories of the time at different points of time. We examine narratives in water management in England and Wales and in the Netherlands, in both instances at a high point of self-conscious modernity in the late 19th century, and then again in the late 20th century in the decade of globalization, seeking thus to elicit evidence for or against any impact of globality on the divide. 
We found our sources in public policy narratives around water in the late 19th century in the libraries of the national ministries engaged with water management. ${ }^{1}$ Additionally we consulted monographs of water companies and internal drainage boards. For the present situation in the two countries we conducted a literature survey and 24 interviews with influential water professionals (for list of interviewees, see Appendix). ${ }^{2}$ Both periods had their own grand narratives - progress in the 19th century, globalization now - and it is through narrative analysis that we expect to find their influence in the documentary and oral sources of the times.

\section{Narratives of Progress in 19th-Century Water Management}

The 19th century saw the rewriting of history to make the nation state its main agent, contributing to the story of humankind as the advance of civilization. Britain and the Netherlands adhered equally to this grand narrative and in both water management became an icon for progress. In both countries health was endangered by industrialization. Industrial emissions and increasing volumes of domestic sewage from the towns caused pollution of local drinking water sources. The sewers introduced in the early 19th century carried untreated waste into the rivers and canals. Cholera epidemics caused water management to become increasingly prominent as an issue for the public agenda. The country's mastery of the supply and quality of water then became testimony to its achievement of a still higher degree of civilization. To this extent if the public-private divide were simply a function of modernity we might expect that the two countries would converge on similar constructions of it as applied to water. After all the idea of progress itself implied eventual convergence on a single most rational system. Yet we find that Britain and the Netherlands clung stubbornly to distinctive national approaches, despite their common adherence to the idea of progress.

\section{SEWERAGE NOT SAVAGERY: THE BRITISH CASE}

Britain's worst cholera epidemic occurred in 1849 when in the London registration districts over 14,000 people died out of a population of about 2,286,000 (Metropolitan Water Board, 1961: 30). It was not until the 1854, through a study by John Snow, that it became known that polluted water was the principal agent in the spread of the disease (Metropolitan Water Board, 1961: 31) The appalling condition of the towns is reflected in the term 'the Great Stink' of 1858. The smell of the Thames was so bad that Government considered moving the House of Commons to another place because it was unbearable (Hassan, 1998: 29).

In response, local authorities provided water free of charge to the poor. There were legislative initiatives addressing the sanitary and pollution problems of water supply and source development (e.g. Public Health Act 1875, 
the River Pollution Prevention Act in 1876). Local authorities bought privately owned water companies and there was some degree of coordination, aiming to control the monopolies with regard to price-fixing (see Dicke, 2001: 75).

Growing state interference, with the nation state expanding as a coercive body, belongs to our first field of modern discourse with the public and private spheres divided between state and market. The story of water confirms that the divide was deeply implicated in the grand narrative of modernity where the nation state was the central agency in a story of human advance, known as 'progress'. In this account Great Britain's attainment of an advanced stage of civilization brought with it the obligation of a civilized society to elevate the poor from their savage circumstances. Since moral degradation and physical pollution were entwined, the state had a mission to provide sewerage and water supply. In other words: water management was considered a key aspect of progress. Sewerage would bring society to a higher plane of civilization. If 'cleanliness was next to godliness' faith in progress happily was also profitable:

The constant relation between the health and vigour of the people and the welfare and commercial prosperity of the State requires no argument. Franklin's aphorism 'public health is public wealth' is undeniable. But what is more important still is the close connexion between physical and moral pollution; ... The mere money cost of public ill-health, whether it be reckoned by the necessarily increased expenditure, or by the loss of work both of the sick and of those who wait upon them, must be estimated at many millions a year. (Royal Sanitary Commission, 1871:15-16)

The reference here to the American Benjamin Franklin, apostle of personal freedom and of self-improvement through hard work, discoverer of electricity, provided clinching authoritative support for the idea of health as a public good and for linking technical advance with moral progress. Later public health reports were emphatic that clean water was integral to human progress:

I am sure that I do not exaggerate the sanitary importance of water, when I affirm that its unrestricted supply is the first essential of decency, of comfort, and of health, that no civilisation of the poorer classes can exist without it. (Simon, 1887: 9, emphasis added)

... the manner in which a people may relapse into the habits of savage life, when their domestic condition is neglected, and when they suffered to habituate themselves to the uttermost deptbs of physical obscenity and degradation. (Simon, 1887: 36, emphasis added)

These references to savagery and civilization echo another American, Lewis Morgan, whose classic, Ancient Society (Morgan, 1877/1976) set out the theory of progress through stages of savagery, barbarism and civilization that was equally influential on English bureaucrats and on Marx and Engels. 
'GOD CREATED THE WORLD BUT THE DUTCH MADE HOLLAND'

As in England and Wales, water management symbolized progress in the Netherlands, but in this case the civilizing mission and concern for public health were less important than the technical achievements of the new profession of engineers. The Dutch highlighted grand projects in water management also as a sign of national prowess and progress.

We can understand the difference between the UK and the Netherlands with the help of the well-known proverb 'God created the world, but the Dutch made Holland'. There is a literal truth in this in a country two thirds of which would be inundated regularly without water management. Water management is therefore existential for the Dutch. Canals were dug. Flood defences celebrated the grandeur of the nation state, e.g. with the excavation of the North Sea canal, begun in 1865, with the creation of a new connection between Rotterdam and the sea (Lintsen, 2002: 559), and with new plans for reclamation of the Zuider Zee. In the Dutch story of progress, patriotism is a major theme, as is illustrated by the Prime Minister's declaration on this major reclamation project: 'Among the public works that are carried out in the Netherlands in the course of time, there is not a single work that is the equal of the closing of the Zuiderzee. And that in every respect. As revelation of the engineer's art, but especially as expression of national vigour' (Colijn et al., 1932: vii).

Belief in the technical capability of the engineers was almost unlimited and so was their prestige (see for example Lintsen, 2002: 359). The idea was that their technical knowledge could also be applied to improve society. An engineer was truly a universal organizer: 'If I may give you a definition of what an engineer is, then it is this: every engineer must first start by constructing in iron; then slowly go over to constructing in people, and finally come to constructing in business cycles' (Ernst Hijmans in an address at a meeting of the Union of Netherlands Manufacturers' Associations, cited in Disco, 1990: 265).

These projects helped to legitimize the state as the agent of modernization. The 19th century was a time in which the state bureaucracy expanded in Dutch water management. Issues of a supra-local nature in water management promoted greater centralization. In the middle of the century a clear division of national and provincial public works departments was established. From then on, the national body 'Rijkswaterstaat' could devote itself completely to overseeing public works and executing projects of national importance (Lintsen, 2002: 557). The state's expansion encompassed developments that made it the main agency of progress.

THE THIRD DISCOURSE: COMMUNITY AS PUBLIC

Differing social and environmental conditions contributed to the respective Dutch and English emphases on health and engineering in their accounts of modernity, even while adhering to a common view of the advance of the state 
as bearer of the public interest. To this extent these stories conform to the widely held view that the consolidation of the nation state was the specifically modern achievement. Yet there were telling counter-stories of water as a public good owing nothing to the central state, harking back to a narrative of cultural identity forged in earlier times.

For the English there was the idea of self-government. They regarded it as a longstanding distinctive feature of their society as opposed to the 'continental nuisance' of bureaucracy (Albrow, 1970: 25). The Royal Sanitary Commission of 1871 alluded to 'the spirit of that self-government' even while pointing to its drawbacks (Dicke, 2001: 84). Second, English accounts of water as a public good also made use of the image of a pre-modern community while lamenting the loss of natural social bonds under commercial pressure: 'Formerly it was the duty of a municipality to supply its townsmen with water, while countryfolk enjoyed a pure river. Of late years joint-stock companies have undertaken this duty as a speculation and matter of gain ...' (Montagu, 1871: 344). Of course this lament for community lost is itself a modern theme, the romantic counterpart and critique of progress. It does not of itself establish a pre-modern reality.

By contrast in the Netherlands the ever-expanding role of the central state bureaucracy was countered by a fully expressed pre-modern definition of the public-private divide in terms of citizenship. In the state-market version of the public-private divide the first commandment is that the nation state separates the two spheres in a hierarchical and unambiguous way (cf. Reinicke, 1998: 6). We would expect this especially in the case of water management since, in most countries, water management consists of 'largescale, centralized hierarchies, in which coordination was imposed from above'. However: 'The Netherlands is different.' Systems in the Netherlands have been established 'without coercion from above' (Kaijser, 2002: 522). The evidence for this is the survival of the waterboards as the oldest democratic bodies in the Netherlands going back to the 12th century, arising out of the collective response to the threat of flooding. Citizens had then to pay a 'contribution' instead of taxes (Belonje, 1945: 125) and there has always been a link, until today, between what is known as the 'triplet', 'interest-paymentvoice'. In these respects, the waterboards resemble a club or an association more than the public body as defined by modern discourse. In other words in connection with water a public realm corresponding with the oldest concepts of a community of citizens has existed in the Netherlands from pre-modern times. The waterboards survived a crucial confrontation with central state notions of the public-private divide in 1848 when a new Constitution sought to assimilate the old waterboards by designating them as public bodies. However, non-modern traits, such as the 'triplet' remained in place. Waterboards remain as communities with active citizenship, instead of 'neutral' public bodies, and are testimony to the vitality of a much older conception of the public sphere. 
SUMMARY

In the 19th century both in the Netherlands and Britain the nation state was positioned as main actor in an overarching grand narrative of advancing civilization. Water management was a key aspect of that progress. Yet the emphasis on the state as guardian of the public realm did not eliminate differences that arose from environmental and social conditions, or suppress narratives that pointed to subsisting cultural differences born of national experience. The idea of a public realm still connected to community existed as a critique of the state and market in both countries, and in the Netherlands survived as a real alternative to central state administration. We shall now look for the ways in which water is lodged in the grand narrative of our time and thus provide a reality test for the 19th century's faith in progress through the state's control of the public realm.

\section{The Global Water Crisis}

The most obvious point about the West's story of itself in the late 20th century is that it no longer centres on progress. As many commentators have pointed out, the boundless optimism of the old modernity has been replaced with an acute consciousness of the limits to growth, or risk and a global catastrophe. Water as the universal necessity and threat occupies an equivalent place in the new narrative to that which it held in the old. But the nation state has been displaced as the main actor.

The dominant narrative now tells of the management of water systems in a state of growing crisis. Industrialization and population growth increase demand while institutions fail to ensure security of water supply. An appeal to the idea of water supply as a human right as well as public good has displaced the hegemony of nation state agency in defining public and private spheres.

Many narrators, including politicians, engineers, scientists, activists and journalists tell the dominant world story of water management. They share a water system approach that views all aspects of water - pollution, floods, dams, drinking water, bathing water, irrigation, etc. - as interrelated. Every major intervention in the water system will have effects elsewhere (Warner, 2000). The inference is drawn, therefore, that water should be managed at a level that takes the entire water system into account. This is the explicit starting point of the European Framework Directive on Water Policy (European Parliament, 2000). It figures prominently in many international publications, for example in the Dublin Declaration of 1992, and in the convention on non-navigational uses of transboundary watercourses of the UN of 1997 (Van Ast, 2000: 559). It is also the official starting point of the World Water Vision of the second World Water Forum (Cosgrove and Rijsberman, 2000: 88), in water projects of the World Bank and in the most recent World Summit on Sustainable Development, in Johannesburg, 2002. 
The narrators of the new story declare that water is a global public good and they claim to speak for humankind. They speak of a man-made crisis, not of scarcity in itself, but of a failure of governance. We can observe water wars taking place, conflicts over massive dams, and rivers that cross borders. Institutional failures leave millions of people vulnerable to disasters such as floods, droughts, cyclones and pollution.

The costs, social, environmental and economic, associated with the water crisis are distributed unevenly. It particularly hits poor countries, and women and children suffer most. The water crisis is not just associated with poverty it is at the core of the problem. Guaranteeing water security is vital to eradicating poverty (US Water News Online, 2002). The magnitude of the crisis cannot be exaggerated. The death toll of the water crisis even exceeds the projected deaths from the global AIDS epidemic (Pacific Institute of Oakland, 2002). 'In this sense, we are all desert dwellers' (World Water Council, 2002: 14). At the World Summit on Sustainable Development in Johannesburg, 2002, it was proposed to recognize water as a basic human right.

If water security is a basic right for all individuals, water cannot be viewed as a commodity, but should be considered as a common public good (United Nations Educational, Scientific and Cultural Organization [UNESCO], 2002). The bottom line is that water belongs to us all (International Water Working Group, 2002). Not the state but humankind owns water and individual nation states are failing to guarantee water security. 'The global public goods approach proposes to implement, on a world scale, policies aimed at correcting market deficiency and at securing for all actors in the global economy access to global public goods (Ministry of Foreign Affairs and Ministry of the Economy, Finance and Industry, France, 2002: 3). The current institutional make up is inadequate to overcome the water crisis. What is needed is a global goods approach that is characterized by a holistic approach to development, which is people centred, gender-sensitive and sustainable (Franciscans International, 2002).

The contrasts between the water system approach and the old modern narrative of progress are profound. First, instead of the modern dream of the possibility of total human control over nature the water system approach speaks of resilience. Science no longer has unlimited potential. The idea has become dominant among water professionals that water can only be controlled to a certain extent. Prince Charles voiced concerns after the storms in 2000 when he declared that the weather chaos plaguing Britain was the result of mankind's 'arrogant disregard for the delicate balance of nature' (Cable News Network [CNN], 2000).

Second, the old modern narrative was built around nation states (Albrow, 1996). But public policy narratives based on the water system approach question the role of the nation state for water management even in wealthy countries. In one of our interviews a senior Dutch civil servant even questioned 'whether there was still a role to be played on the level of the 
nation state, now that international river authorities are to be established with the European Framework Directive' (see Dicke, 2001: 186-7).

For some the recasting of water as a global public good within a water system approach is the next stage of modernization. Van Ast (2000: 556) for example states that it is 'obvious that the disappearance of national borders [in river management] is part of the current modernization process'. But given that the nation state was the central agency in the old modernity this looks more like modernization gone into reverse. In our view it suggests a shift to a new baseline in the grand narrative repertoire, from nation to globality. But if no longer centre stage in the unfolding story, what is the new role for the nation state and which agency or agencies take the lead? To throw light on these questions we return to Britain and the Netherlands, but this time in the late 20 th century.

\section{Dutch and British Responses in a European Framework}

In both countries, water management is conducted comprehensively. The point of departure is no longer control of water, but its accommodation (e.g. NRLO, 2000). This puts into perspective the possibilities of human intervention. Engineers are no longer the uncontested heroes of society. In the Netherlands, the water system approach is expressed in the term 'transnational water' (Van Hall, 1999). It acknowledges that water transgresses and renders national boundaries irrelevant.

The water systems approach permits a wide range of institutional arrangements for water management. The Dutch have recently strengthened the public hand in water management. It is statutory that the delivery of water services to households is confined to public water companies (Ministerie van Volkshuisvesting, Ruimtelijke Ordening en Milieu [VROM], 2000). The reasoning is that water systems are pure common goods and private companies cannot be trusted with the provision of drinking water, which is only one aspect of the water system (De Waterkring, 1998).

By contrast the British drinking water sector was completely privatized in 1989 , a process described by the regulator as 'the most complete privatization of water services to be found anywhere in the world' (Byatt, 1997: 1). Yet British water management also subscribes to the water system approach. While private companies provide water services, they are subject to several regulators (for the environment, for the customer, for competition, for water quality) who engage in public discussion. For example, if the environmental regulator (Environment Agency [EA]) proposes new regulatory measures, the director of a drinking water company will argue that the tariffs for the consumer will have to rise. The regulator who represents the interests of the consumers (Office of Water Services [Ofwat]) will ask about the need to make the investments. Do we need to make them right now? If so can we distribute 
the costs evenly over several generations? Before privatization, the prioritization of different public values took place behind closed doors. As of now, it is all done 'in the public eye', as a director of a water company told us in an interview. This transparency in the prioritization of different public values sustains the old usage of calling the water companies 'public utilities' even though they are now privately owned.

The water system approach appears to be associated with institutional innovation that permits both differing national responses and new transnational initiatives. Both Britain and the Netherlands seek to implement European directives. A modernist interpretation would see this as an instance of European aspirations for superstate status. But the 'Euronarrative' for water appeals to principles that challenge the old values central to the statecentred narrative of progress. In proclaiming river basins as the basic unit of management, it delinks public from national boundaries and links European management of water to the capability of humankind to develop institutions for water as a common global resource. The river basin then becomes a new base for a redefined public interest detached from the old national collectivity. The open issue is not whether, but what new kinds of collectivity will emerge to serve this newly defined public interest.

In both countries, we see this reflected in attempts to establish a link between water and society, where society can mean all kinds of 'public participation' (an explicit requirement mentioned in the Water Framework Directive). Participation is a touchstone for the existence of a community of citizens, the third field of public-private discourse we identified, where collective control takes place in the open. But the society or collectivity is no longer necessarily local community or nation state. In Wales for example, in May 2001 Glas Cymru took over Welsh Water and became the main supplier in Wales. It is a 'Company limited by guarantee' registered under the Companies Act 1985. Instead of shareholders the company has Members, i.e. individuals from Wales appointed by an independent selection panel. Around 50 Members have been appointed to carry out the same corporate governance role shareholders do. Their main task is to ensure the company focuses on providing high quality water and sewage services at least cost.

This new type of ownership serves several aims: to protect and balance public values; to protect captive users; to distribute the rewards of efficiency in terms of lower bills to customers rather than dividends to shareholders; and, to bring the company closer to consumers. The search for a 'third way' in ownership types is also linked to financial regulation. Under a price cap set by the economic regulator there is a premium on increased efficiency if profits are to increase.

These innovations suggest however that the idea of 'a third way' to be found between state and market is an inadequate formulation for the transformation where 'society' is introduced to engineer hybrid public-private agencies. There are innumerable possibilities (explored by others for instance in public 
administration [Vigoda, 2002] or social services [Van Slyke, 2003]). The demand for visibility (transparency) for the new institutions and the appeal to a non-national public sphere suggests a reconstitution of the public-private divide that transcends the ideological debates of old-style national politics. In this new discourse the nation state becomes a facilitator, sometimes an agent for the global public, even occasionally a private interest relative to the concerns of humankind.

\section{The Current Reconstitution of the Public-Private Divide}

The evidence from the narratives of contemporary water management suggests that practitioners are engaged in an effective reconstitution of the public-private divide that takes it beyond earlier theoretical debates. This article is empirical rather than theoretical but its conclusion is that the theory needs to catch up with the practice. The two assumptions in both scholarly and political debates have been that public goods are national in character (Kaul et al., 1999: 9) and that the nation state consolidates the public and private spheres into a single territorial entity (Reinicke, 1998: 6). This was also true for water management until the emergence of the narrative of globality. Orientation to the globe stimulates new kinds of collectivity at both local and global levels. Ostrom (1990) has argued strongly that local social units of limited size have been very successful in developing enduring institutional arrangements to preserve common pool resources. The recent history of responses to globalization shows that transnational networks of local activists can engage effectively with global issues. The example of water is an answer to sceptics (Smith, 1995) who believe the undoubted resilience and durability of national identity preclude the development of a global level public sphere. But what we can concede to them is that this sphere is now constituted more in the global media of communication rather than in anything that replicates national politics on a global level. We may have global citizens but nothing like a global nation state (cf. O'Byrne, 2003).

When we bring visibility back into the frame then we want to identify the participating agents, clarify whom they represent and trace the flow of benefits. There is no obvious citizen community corresponding to global public goods and yet this is what the combination of control and visibility in the third field of discourse has always required. It is these questions that have turned control issues, questions of public or private ownership, into matters of technical interest only, whereas under the old modernity they were central to class politics. But we cannot go back to the unitary public-private divide of the Roman Republic, the lost world that still underpins the ideal Habermasian state. As Calhoun says, the world of today contains many publics. His focus was on the representation of transnational cultural diversity within the state. Our concern has been with the multiple agencies that assume global respon- 
sibilities, where water systems not state boundaries become their ordering principle, and globality requires the active involvement of the riparians (Bernauer, 1997: 192).

Thus, the older discourses of the public-private divide are being replaced by the new conception of a public interest served by multiple organizational forms of company, community and citizenship. Both the pre-modern Dutch waterboards and the postmodern Glas Cymru are able to work within the European Framework Directive for the global public good. In these respects our work on water is consistent with the conclusions of recent similar comparative, historically grounded work on the health care systems of the Netherlands and England (Kumpers et al., 2002).

Our evidence from the story of water management is that both in the Netherlands and the UK is that the public sphere is being reconstituted in response to globality. Its definition no longer lies within the domain of the nation state, but is the outcome of the activities of new kinds of communal organization. Central in these innovations is that they reunite the visibility and control dimensions that the moderns had sought to separate and which critics of modernity have lamented. But the result is not a revival of ancient direct democracy, but agencies of all kinds delivering goods to a virtual global public and submitting themselves to high standards of transparency. Political community has returned, but in the new guise of global civil society, and each nation state has to find its own way of learning to live with it.

NOTES

1. These were the Department of the Environment, Transport and the Regions for the UK (now called Department for Environment, Food and Rural Affairs), and the Department for Public Works and Water Management, the Ministry of Housing, Spatial Planning and the Environment for the Netherlands. These libraries retain all the material of their predecessors. The antique collection contains books, journals for engineers, minutes of the annual meetings of professional organizations of engineers, and plans. In the Netherlands we have also made use of the 'Trésor' in the library of Delft University. This place was the cradle of all Dutch water engineers during this period. The 19th-century collection contains books, journals for engineers, minutes of the annual meetings of professional organizations of engineers, plans, biographies and study books for the engineers-to-be at that time.

2. An analysis of documents resulted in the inventory of the structure of water management in the two countries and its institutional framework. On the basis of the institutional framework, we have sought representatives of the most important organizations, bodies and movements. Those interviewees mentioned other key persons in water management, either for their key role in policy making, or for their influential role in the public debate. We have interviewed 24 persons. The interviews were 'narrative interviews' (Czarniawska, 1998: 29), meaning that both the structure and the main concepts are chosen by the interlocutor rather than the researcher. All interviews were conducted in the period 1999-2001. 


\section{REFERENCES}

Albrow, M. (1970) Bureaucracy. London: Pall Mall Press.

Albrow, M. (1996) The Global Age: State and Society beyond Modernity. Cambridge: Polity.

Arendt, H. (1958) The Human Condition. Chicago, IL: Chicago University Press.

Belonje, J. (1945) Het Hoogheemraadschap van de Uitwaterende Sluizen in Kennemerland en West-Friesland, 1544-1944 [The Waterboard of 'Uitwaterende Sluizen in Kennemerland' and 'West-Friesland']. Wormerveer, The Netherlands: Meijer's Boek.en Handelsdrukkerij.

Bernauer, T. (1997) 'Managing International Rivers', in O.R. Young (ed.) Global Governance: Drawing Insights from the Environmental Experience (pp. 155-96). Cambridge, MA: MIT Press.

Biermann, F. and Dingwerth, K. (2004) 'Global Environmental Change and the Nation State', Global Environmental Politics 4(1): 1-22.

Braithwaite, J. and Drahos, P. (2000) Global Business Regulation. Cambridge: Cambridge University Press.

Byatt, I. (1997) 'Water Regulation in England and Wales: The Strategic Approach and Way Ahead', speech delivered at the Technical Conference Lyonnaise des Eaux Water Division, Redworth Hall, near Darlington.

Cable News Network (CNN) (2000) 'Storms Rage on Across Europe', accessed 3 July 2001, available at http://www.cnn.com/2000/World/Europe/11/07/storms.deaths. 02/index.html

Calhoun, C. (1997) 'Nationalism and the Public Sphere', in J. Weintraub and K. Kumar (eds) Public and Private in Thought and Practice, Perspectives on a Grand Dichotomy (pp. 75-100). Chicago, IL: University of Chicago Press.

Christen (2003) 'Global Reporting Initiative', http://www.globalreporting.org/

Colijn, H., Van Kampen, H.C.A. and Kloeke, G.G. (eds) (1932) De Zuiderzee: Een Herinneringswerk [The ZuiderZee: A Mental Picture]. Amsterdam: Scheltema \& Holkema's Boekh. en Uitgevers Mij NV.

Cosgrove, W. and Rijsberman, F. (2000) World Water Vision: Making Water Everybody's Vision. London: World Water Council.

Czarniawska, B. (1998) A Narrative Approach in Organization Studies. Thousand Oaks, CA: Sage.

Deacon, B. (eds) (2003) Global Social Governance: Themes and Prospects. Helsinki: Finnish Ministry of Foreign Affairs.

Dicke, W.M. (2001) Bridges and Watersheds: A Narrative Analysis of Water Management in England, Wales and the Netherlands. Amsterdam: Aksant.

Disco, C. (1990) 'Made in Delft, Professional Engineering in the Netherlands 18801940'. Amsterdam: Universiteit van Amsterdam.

Elias, N. (1939/1978/1982) The Civilizing Process, 2 vols. New York: Pantheon.

European Parliament (2000) 'Directive 2000/60/EC of the European Parliament and of the Council Establishing a Framework for the Community Action in the Field of Water Policy, the EU Water Framework Directive', in the Official Journal L 327, 22/12/2000 P. 0001-0073, accessed 9 March 2005, http://europa.eu.int/smartapi/ cgi/sga_doc?smartapi!celexapi!prod!CELEXnumdoc\&lg=en? mdoc=32000L0060\& model=guichett

Franciscans International (2002) 'Statement by Franciscans International, an NGO in General Consultative Status with ECOSOC and by VIVAT International, an NGO accredited to the World Summit of Sustainable Development Process', accessed 4 
November 2002, http://www.vivatinternational.org/vifistatementwssdjohannesburg. $\mathrm{html} / /$

Gardner, R., Ostrom, E. and Walker, J.M. (1990) 'The Nature of Common Pool Resource Problems', Rationality and Society 2(3): 335-58.

Global Environmental Facility (GEF) (2004) Stuk Martin [Projects], accessed 9 March 2005, http://thegef.org/Projects/projects-Projects/projects-projects.html

Habermas, J. (1962/1989) 'The Structural Transformation of the Public Sphere: An Inquiry into a Category of Bourgeois Society'. Cambridge, MA: MIT Press.

Hassan, J. (1998) A History of Water in Modern England and Wales. Manchester: Manchester University Press.

International Water Working Group (2002) 'Defend the Global Commons', Reports from Organizations Around the World Defending Water as a Common Resource 1(2).

Kaijser, A. (2002) 'System Building from Below: Institutional Change in Dutch Water Control Systems', Technology and Culture 43(3): 521-49.

Kaul, I., Grunberg, I. and Stern, M.A. (1999) 'Defining Global Public Goods', in I. Kaul, I. Grunberg and M.A. Stern (eds) Global Public Goods (pp. 2-20). New York: Oxford University Press.

Krasner, S. (1982) 'Structural Causes and Regime Consequences: Regimes as Intervening Variables', International Organisation 36(2): 185-205.

Kumpers, S., Van Raak, A. Hardy, B. and Mur, I. (2002) 'The Influence of Institutions and Culture on Health Policies: Different Approaches to Integrated Care in England and the Netherlands', Public Administration 80(2): 339-58.

Lintsen, H. (2002) 'Two Centuries of Central Water Management in the Netherlands', Technology and Culture 43(3): 549-69.

Metropolitan Water Board (1961) The Water Supply of London. London: MWB.

Ministerie van Volkshuisvesting, Ruimtelijke Ordening en Milieu (VROM) (2000) 'Overdracht Waterleidingbedrijven Aan Niet-Overheden Niet Meer Mogelijk' [Transfer of Drinking Water Companies to Private Parties No Longer Possible], accessed 23 December 2000, http://www.minvrom.nl/minvrom/pagina.html?id=2611

Ministry of Foreign Affairs and Ministry of the Economy, Finance and Industry, France (2002) Global Public Goods. Paris: Ministry of Foreign Affairs and Ministry of the Economy, Finance and Industry.

Montagu, R. (1871) 'Watershed Boards or Conservancy Boards for River Basins', Second Report of the Royal Sanitary Commission, Vol. II. London: Her Majesty's Stationery Office.

Morgan, L.H. (1877/1976) Ancient Society: Or, Researches in the Lines of Human Progress from Savagery through Barbarism to Civilization. New York: Gordon Press.

Nationale Raad voor Landbouwkundig Onderzoek, Adviesraad voor het Wetenschaps- en Technologiebeleid and Raad voor het Milieu en Natuuronderzoek (NLRO) (2000) Over stromen: Kennis en Innovatieopgaven Voor Een Waterrijk Nederland [On Water: Tasks concerning Expertise and Innovation for Water Management in the Netherlands]. Rijswijk, The Netherlands: NLRO.

O'Byrne, D. (2003) The Dimensions of Global Citizenship. London: Frank Cass.

Ostrom, E. (1990) Governing the Commons: the Evolution of Institutions for Collective Action. Cambridge: Cambridge University Press.

Pacific Institute of Oakland (2002) 'Dirty Water: Estimated Deaths from WaterRelated Diseases 2000-2020'. California: Pacific Institute of Oakland, accessed 9 March 2005, http://www.pacinst.org/reports/water_related_deaths/water_related_ deaths_report.pdf 
Reinicke, W. (1998) Global Public Policy: Governing without Government? Washington, DC: Brookings Institute Press.

Reinicke, W. and Deng, F.M. (2000) 'Critical Choices: The United Nations, Networks, and the Future of Global Governance', Report of the UN Vision Project on Global Public Policy Networks, March. Ottawa: International Development Center.

Royal Sanitary Commission (1871) Second Report of the Royal Sanitary Commission. London: Her Majesty's Stationery Office.

Smith, A. (1995) Nations and Nationalism in a Global Era. Cambridge: Polity.

Simon, J. (1887) Public Health Reports, Vol. 1. London: Offices of the Sanitary Institute. United Nations Educational, Scientific and Cultural Organization (UNESCO) (2002) 'Water Is Not a Commodity, But a Common Public Good', Media Advisory No. 2002-32, accessed 17 November 2002, http: www.unesco.org/bpi/eng/unescoprewss/ 2002/02-avis324.shtml

US Water News Online (2002) 'Water Key to Ending Africa's Poverty', accessed 17 November 2002, http://www.uswaternews.com

Van Ast, J. (2000) Interactief Watermanagement in Grensoverschrijdende Riviersystemen [Interactive Water Management for Transboundary Rivers]. Delft, The Netherlands: Eburon.

Van Hall, A. (1999) Transnationaal Water: Europese Ontwikkelingen, van Idealen naar Werkelijkheid 'Watersysteembeheer, de Grens Over. Opstellen ter Gelegenheid van de faarvergadering 1999 van de Vereniging Waterstaatsbestuur en Waterstaatsrecht' [Transnational Water. European Developments: From Ideals to Reality]. Maastricht: Shaker Publishing.

Van Slyke, D.M. (2003) 'The Mythology of Privatization in Contracting for Social Services', Public Administration Review 63(3): 296-315.

Vigoda, E. (2002) 'From Responsiveness to Collaboration to Collaboration: Governance, Citizens and the Next Generation of Public Administration', Public Administation Review 62(5): 527-40.

Warner, J. (2000) 'Integrated Management Requires an Integrated Society', accessed 9 March 2005, http://www.wca-infonet.org/cds_upload/1070041590138_ management.pdf

Waterkring, De (1998) De Waarden van Water: Een Manifest [The Values of Water]. Den Haag, The Netherlands: De Waterkring.

Weintraub, J. (1997) 'The Theory and Politics of the Public/Private Distinction' in J. Weintraub and K. Kumar (eds) Public and Private in Thought and Practice, Perspectives on a Grand Dichotomy (pp. 1-43). Chicago, IL: University of Chicago Press.

Wittfogel, K.A. (1957) Oriental Despotism: A Comparative Study of Total Power. New Haven, CT: Yale University Press.

World Bank (1993) 'Water Resources Management', Policy Paper. Washington, DC: World Bank.

World Water Council (2002) 'World Water Actions', Third Draft, 31 October 2002, accessed November 2002, http://www.worldwatercouncil.org/download/WWA latest_version.pdf 
RÉSUMÉ

\section{Comment Combler le Vide Entre le Public et le Privé dans des Conditions de Mondialisation? Les cas Britannique et Hollandais dans la Gestion de l'eau}

Comment pouvons nous tracer la démarcation entre le public et le privé lorsque ceux qui doivent combler le vide sont aussi ceux pour lesquels une telle division limite la capacité de l'état de tenir ses engagements en matière de politiques publiques? Les critiques de la modernité se sont rendus compte d'un double discours public - privé, celui de l'état et le marché, du découvert et du caché, et qu'ils conçoivent comme une mauvaise version moderne des notions classiques de la communauté démocratique de citoyens. La projection de cette démarcation sur une scène mondiale semblerait nous écarter encore plus loin de cet idéal. Dans cet article on fait le compte rendu des résultats d'un examen descriptif de la manière dont les chargés de fournir le service social de gestion de l'eau par rapport à la façon dont leurs prédécesseurs du dixneuvième siècle fournissaient les services de santé publique et de progrès social. Dans leur soutien au concept de systèmes d'eau on trouve aussi leur soutien actif à une sphère publique transparente au-delà de l'état et où des formes différentes d'action confirment des responsabilités mondiales.

RES UMEN

\section{Cerrando la Brecha entre los Sectores Público y Privado en Condiciones de Globalización: Los Casos Británico y Holandés en la Gestión del Agua}

¿Cómo se debe trazar la línea divisoria entre lo público y lo privado cuando quienes los encargados de cerrar la separación son también los que sostienen que la globalización restringe la capacidad del estado de cumplir con los objetivos de política pública? Los críticos de la modernidad se han dado cuenta de la diferencia entre dos discursos público-privado, el del estado y el del mercado, el descubierto y el oculto, como mala versión moderna de las nociones clásicas de la comunidad democrática de ciudadanos. La proyección de esta línea divisoria a un escenario mundial parece apartarnos aún más de dicho ideal. En este artículo informamos sobre los resultados de un análisis descriptivo de la manera en que los encargados de Holanda, Inglaterra y Gales proporcionan el servicio público de administración del agua, en comparación con la manera en que sus predecesores administraban los servicios de salud pública y progreso social en el siglo 19. En su respaldo al concepto de sistemas de suministro de agua encontramos también su respaldo activo a una esfera pública transparente más allá del estado donde las diferentes formas de acción afirman responsabilidades globales. 
BIOGRAPHICAL NOTES

WILLEMIJN DICKE is assistant professor in Organization \& Management, Faculty of Technology, Policy and Management. Her areas of expertise are issues evolving around the public-private divide, especially with regard to the safeguarding of public values and interests in water management; global public goods and their institutional embedding in transnational networks; and, finally the use of the method of narrative analysis for the practice of policy analysis. Please address correspondence to: Willemijn Dicke, Delft University of Technology, PO Box 5015, 2600 GA Delft, The Netherlands. [email: W.Dicke@tbm.tudelft.nl]

MARTIN ALBROW has held professorial appointments in Cardiff, Munich, Roehampton, Cambridge, London School of Economics and the State University of New York, Stony Brook. He was a fellow at the Woodrow Wilson International, Center for Scholars, Washington DC. His books include Bureaucracy, Max Weber's Construction of Social Theory, Do Organizations Have Feelings? and The Global Age, which won the European Amalfi Prize in 1997. He is currently Visiting Fellow, Centre for the Study of Global Governance, London School of Economics. Please address correspondence to: Martin Albrow, 4 Lawrie Park Crescent, Sydenham, London SE26 6HD. [email: albrowm@hotmail.com] 
APPENDIX List of interviewees in England and Wales

Customer Service Committee Ofwat (England)

Customer Service Committee Ofwat (Wales)

Department of the Environment, Transport and

Regions, Water and Land Directorate (now

Department for Environment, Food and Rural Affairs

Drinking Water Company

Drinking Water Inspectorate

English Nature

Environmental Movement

Environment Agency

Internal Drainage Board

Internal Drainage Board

Ministry of Agriculture, Fisheries and Food

Ofwat

Water UK
Secretary to CSC

Secretary to CSC

Senior civil servant

Chief Executive Officer

Head of DWI

Senior Freshwater Officer

Officer responsible for the biodiversity campaign

Senior Water Resource

Manager

President of the Board

Engineer to the Board

Environmental Adviser to

flood and coastal defence

Chief Engineer and Senior

Officer

Regulatory Adviser

List of interviewees in the Netherlands

Consultancy Firm

Consumer Organization (Consumentenbond)

Environmental NGO

Ministry of Economic Affairs (Economische Zaken)

Ministry of Housing, Spatial Planning and the Environment (Ministerie van Volkshuisvesting, Ruimtelijke Ordening en Milieu)

Ministry of Transport, Public Works and Water Management (Ministerie van Verkeer en Waterstaat)

Province

Waterboard 1

Waterboard 2

Waterboard 3

Water Company
Consultant in Utilities, especially the water industry, working in England and the Netherlands

Senior Officer

Staff member

Civil Servant at Directorate

General Industry and Services

Head of Water Supply and

Waste Water Department

Head of Water Policy Division

Senior civil servant

President (Dijkgraaf)

President (Dijkgraaf)

Head of International Affairs

Director 